\title{
Mentored Clinical Scientist Development Award (K08)
}

National Cancer Institute

\section{Source}

National Cancer Institute. Mentored Clinical Scientist Development Award (K08). NCI

Thesaurus. Code C18872.

To provide the opportunity for promising medical scientists with demonstrated aptitude to develop into independent investigators, or for faculty members to pursue research aspects of categorical areas applicable to the awarding unit, and aid in filling the academic faculty gap in these shortage areas within health professions institutions of the country. 